\title{
Influence of periphyton substrates and rearing density on Liza aurata growth and production in marine nursery ponds
}

\author{
M. Richard ${ }^{a, b, ~}{ }^{*}$, J.T. Maurice ${ }^{a}$, A. Anginot $^{a}$, F. Paticat ${ }^{a}$, M.C.J. Verdegem ${ }^{c}$ and J.M.E. Hussenot ${ }^{d}$
}

\author{
a IFREMER (Institut Français de Recherche pour l'Exploitation de la Mer), 17137 L'Houmeau, France \\ ${ }^{\mathrm{b}}$ Littoral, Environnement et Sociétés (LIENSs), UMR 6250, CNRS-Université de La Rochelle, 2 rue \\ Olympe de Gouges, F-17042 La Rochelle Cedex 01, France \\ ${ }^{\mathrm{c}}$ Aquaculture and Fisheries Group, Department of Animal Sciences, P.O. Box 338, $6700 \mathrm{AH}$ \\ Wageningen, The Netherlands \\ d IFREMER (Institut Français de Recherche pour I'Exploitation de la Mer), Dept AGSAE, Station \\ d'aquaculture, 85230 Bouin, France
}

* Corresponding author: M. Richard, Tel.: + 332516889 46; fax: + 3325149 34 12, email address : marionrichard fr@yahoo.fr

\begin{abstract}
:
The main objectives of this investigation were to test the effects of (i) the presence of periphyton substrates, (ii) rearing density and (iii) supplemental feeding with dry feed on the growth and production of golden mullet (Liza aurata) juveniles. Twenty-six $1 \mathrm{~m}^{2}$-cages were installed in a French marine pond from April till June 2008. Mullets were stocked in cages with or without substrate at a density of $0,20,40$ or 60 individuals per cage. Each treatment was carried out in triplicate. In addition, 20 fish were put in three tanks and fed ad libitum with dry feed. The results showed that (i) although mullets were seen to graze on periphyton substrates, their presence did not affect mullet growth and production. In future studies, meshed substrates could be attached on hard structures to improve the efficiency of mullet grazing; (ii) individual growth was higher at low density due to a lower competition for space and food. Production increased with rearing density reflecting that food availability was not limiting in control cages; (iii) growth and net yield of mullets were lower in fed tanks than in natural ponds where food seemed to be more appropriate for wild mullet juveniles and where stress factors were lower. Finally, in contrast to the individual growth rate, the net fish yield in this experiment was greater than that recorded in other extensive and semi-intensive systems. It was equivalent to yields observed in other periphyton-based systems. Periphyton developed on the meshed walls of cages probably increased the natural productivity of the pond. As part of sustainable aquaculture development, the effluents of intensive farms could be exploited to produce periphyton on inflexible substrates and to rear mullet adults, which are more herbivorous than juveniles. This type of integrated system could be developed with other mullet species, such as Chelon labrosus or Mugil cephalus, whose growth rates are higher than $L$. aurata. Mullet production could be exploited by the sale of fillets and dried roe.
\end{abstract}

Keywords: Periphyton; Mullet; Extensive aquaculture; Artificial substrate; Marine pond 


\section{Introduction}

The principle of traditional periphyton-based aquaculture is to introduce artificial substrates (e.g. wooden poles or bamboo) to enhance food availability via periphyton development and to increase the production of fish (Ramesh et al., 1999; Umesh et al., 1999; Azim et al., 2004; Milstein et al., 2009). Periphyton-based aquaculture is well developed in tropical fresh and brackish waters for fish culture (van Dam et al., 2002; Azim et al., 2005) but rarely applied in marine environments (Huchette and Beveridge, 2005; Richard et al., submitted).

As part of the European SEACASE (Sustainable extensive and semi-intensive coastal aquaculture in Southern Europe) project (2007-2010), the main objective of the IFREMER (Institut Français de Recherche pour l'Exploitation de la Mer) case study was to test the efficiency of marine periphyton-based systems on juvenile fish production in a temperate region. Three experiments were carried out from 2007 till 2008.

The first experiment showed that more periphyton biomass and chlorophyll $a$ was collected on mosquito screen than on wooden poles, fibreglass slices and garden netting (Richard et al., 2009). The second experiment (Richard et al., submitted) showed that juveniles of seabream (Sparus aurata) fed on periphyton substrates, which acted as suspended benthic interfaces. Seabream juveniles had a top-down control on harpacticoid copepods on these periphyton substrates. Nevertheless, survival, growth rates, and yields were low whatever the substrate presence or stocking density. The food availability per juvenile was certainly limiting in the cages. Thus, the authors recommended (i) longer substrate immersion, (ii) more frequent water renewals, (iii) pond water fertilisation and (iv) a lower initial stocking density of juveniles in subsequent studies to improve the natural food availability per fish at both interfaces. 
In 2008, the third experiment, reported here, tested the influence of periphyton substrates and rearing density on mullet growth and production in French marine ponds.

Mullets eat microphytobenthos, organic detritus, bacteria and meiofauna (Crossetti and Cataudella, 1994; Bruslé, 1981). Juveniles of some mullet species start as planktoniccarnivorous and become benthic-herbivorous at 45-50 $\mathrm{mm}$ e.g. Liza aurata and Liza ramada (Bruslé, 1981). Chelon labrosus, L. aurata, and L. ramada are the most abundant mullets on the French Atlantic coast (Gautier and Hussenot, 2005). Golden mullets, L. aurata, can be found in sheltered mud bottom (Lam Hoai Thong, 1969). They are reared in marine ponds and are much appreciated on the west coast of France (Gautier and Hussenot, 2005) so this species was selected for this experiment.

In this investigation, the following hypotheses were tested: (i) addition of substrates for periphyton development will enhance mullet growth, (ii) the latter will be faster with a low rearing density, (iii) the best production will be obtained at an intermediate rearing density and in the presence of substrates, and (iv) supplemental feeding will result in better growth than in traditional or periphyton-based systems.

\section{Materials and methods}

\subsection{Experimental site, schedule, rearing devices and substrates}

Two experiments were performed in 2008 in the experimental facilities of IFREMER in L'Houmeau (France). The first (PERIMUL) was carried out in one $200 \mathrm{~m}^{2}$ pond with 24 cages made from non-treated wood ( $\mathrm{L}$ x W x D: $1 \mathrm{~m}$ x $1 \mathrm{~m}$ x $1 \mathrm{~m})$. Twenty-cm-long feet maintained each cage above the sediment. The bottom of the cages consisted of a plastic panel (Kommatex). The vertical sides were made from $0.5 \mathrm{~cm}$ meshed polyethylene netting (Richard et al., submitted). The bottoms and walls of all cages were cleaned in the middle of 
March. Meshed substrates were immersed in an adjacent pond in early August 2007, and transferred to the experimental cages on 25 March 2008. The meshed substrates (pieces of mosquito screen: W x L: $5 \times 95 \mathrm{~cm}$ ) were suspended from metal bars placed at the top of the cages (Richard et al. submitted). Each bar carried 7 pieces, and 4 bars were installed per cage, resulting in 28 substrates per cage. The mean surface area of meshed substrate was $77.13 \pm$ $0.34 \mathrm{~cm}^{2}$, with a total additional surface area of $2.16 \mathrm{~m}^{2}$ per cage. Cages were covered by a 14 $\mathrm{cm}$ mesh screen to avoid bird predation. The four vertical sides of the cages were brushed just before fish stocking. From then onwards, two cage sides were cleaned fortnightly to avoid clogging due to fouling. On cleaning days, approximately $20 \%$ of pond water was replaced by tidal exchange.

The second experiment (FEED) was carried out using three $1 \mathrm{~m}^{2}$ fibreglass tanks, located in the laboratory adjacent to the ponds. They were continuously filled with pond water and aerated. Mullets were fed with dry feed $\left(5\right.$ g. $\left.\operatorname{tank}^{-1} \cdot \mathrm{d}^{-1}\right)$, administered in 2 meals per day. During feeding, the water flow was stopped and mullet juveniles were observed eating dry feed on the water surface and at the bottom of the tank. Feed consisted of (i) 30\% Lucky Star, mainly composed of fish, squid and krill meal and (ii) 70\% Skretting/Hendrix Classic C22. As Skretting noted, Classic C22 contains selected vegetable raw materials (soybean, wheat) and animal protein (fish meal and oil; crude protein: $28 \%$ ) ensuring the nutrient requirements of omnivorous species are satisfied. Walls of tanks were cleaned weekly after fish had been transferred to a new cleaned tank. Mullets showed no stress behaviour.

Wild juveniles of L. aurata, purchased from the Venetian coast of Italy, were introduced into cages and tanks on 21 April 2008, called hereafter day 1. Fish were harvested 65 days later on 24 June 2008.

\subsection{Experimental design}

PERIMUL: Influence of periphyton substrate and rearing density 
A $2 \times 4$ factorial experiment was carried out in 24 cages, with 3 replicates per treatment. The first factor was substrate presence, referred to as periphyton (PERI), with no substrate (C) and meshed substrates (S) as levels (Figure 1). The second factor was fish density (DENS) with either 0,20, 40 or 60 mullets per cage (referred to as $0,20,40$ or 60) as levels (Figure 1).

Periphyton samples were taken 5 times during the experiment. The first sampling was done 1 week before stocking (15 April; day - 6). The second was on 12 May (3 weeks after stocking; day 21). The other samples were taken fortnightly until the end of the experiment (26 May, 9 June \& 23 June; days 35, 49 and 63). On sampling days, one meshed substrate was randomly selected per cage.

\section{FEED: Intensive vs. extensive and semi-extensive systems}

A one-way factorial experiment was carried out in 9 experimental units, with 3 replicates per treatment. The main factor was the type of rearing system, referred to as type (TYPE), with substrate-free cages $(\mathrm{C}$, for control), meshed-substrate cages $(\mathrm{S})$, and flow through tanks fed ad libitum with dry feed (F; Figure 2), as levels. Density of fish did not vary according to TYPE and was fixed at 20 individuals. $\mathrm{m}^{-2}$.

In both experiments, samples of 10 mullets per cage or tank were planned on days 1,21 , 35, 49 and 63. From day 35 onwards, collecting 10 fish was difficult, especially in cages that contained low fish density (20; Figure 1). Therefore, the 10-fish sub-sampling was probably not representative of the population in the cage. The data collected on days 21 and 35 were not used for analysis. In addition, sampling on day 49 was skipped. At the end of the experiment on day 63, all mullets were harvested. 
Periphyton-based system of mullets

\subsection{Field sampling and measurements}

\section{Environmental data}

Every day at 2 PM (local time $=\mathrm{GMT}+2)$, temperature, salinity, oxygen concentration and $\mathrm{pH}$ were measured at 3 different fixed sampling locations in the pond, using a HANNA multi-parameter probe (HI 9828). 2L-water samples were collected fortnightly at the fixed sampling sites in the pond. Each 2L-sample was separately filtered through Whatman GF/F filters (25 mm diameter for Chl $a$ and $47 \mathrm{~mm}$ diameter for seston). Filters used for seston weight analysis were pre-burned $\left(450^{\circ} \mathrm{C}\right.$ for $\left.1 \mathrm{~h}\right)$ and pre-weighed. Filters were stored at $20^{\circ} \mathrm{C}$ until analysis.

\section{Periphyton}

Periphyton substrates were collected one day before fish sampling. Each sampling day, the cages were sampled in a random order. One randomly selected piece of substrate was removed per cage, using a PVC tube $(6 \mathrm{~cm}$ diameter x $110 \mathrm{~cm}$ length) and $100 \mu \mathrm{m}$-meshed stopper to avoid periphyton loss. The surface area of each removed piece of substrate was measured $\left(\mathrm{cm}^{2}\right)$. The entire piece was carefully cleaned, using fingers and a toothbrush, into a plastic flask with $200 \mathrm{ml}$ of filtered sea-water $(0.7 \mu \mathrm{m}$ pore size $)$. The sample was next subsampled using a Motoda Box (Motoda, 1959). $1 / 8$ was stored in a dark box at $-20^{\circ} \mathrm{C}$ for $\mathrm{Chl} a$ analysis, $7 / 16$ was stored with $4 \%$ formaldehyde for taxonomic analysis, and 7/16 was used to determine periphyton dry weight and ash-free dry weight. The last fraction was placed directly in a pre-weighed box at $60^{\circ} \mathrm{C}$. The removed substrate piece was replaced by one containing equally old periphyton, grown in two additional fish-free cages installed in the same pond. 


\section{Fish}

On sampling days, the cages were sampled in a random order. The net cover was carefully removed from the cage. The bars with pieces of substrate were gently moved to the side of the cage. Ten fish were collected using a large dip net, transferred to a floating cage and subsequently moved to an aerated aquarium in the lab. Fish were individually weighed (Denver Instrument MXX-612 balance) using a box filled with seawater. After sampling, fish were reintroduced into their original cage. Simultaneously, sampled fish from the feedingtanks were also weighed and replaced. At the end of the experiments, all fish were collected, counted and individually weighed to calculate the final total fish weight and the survival rate per cage or tank.

\subsection{Laboratory processing}

\section{Dry weight and Ash-Free Dry Weight}

Seston and periphyton samples were dried at $60^{\circ} \mathrm{C}$ for $72 \mathrm{~h}$, weighed (DW: dry weight), and combusted for $4 \mathrm{~h}$ at $450^{\circ} \mathrm{C}$ to determine the ash weight (ASH) and thus deduce the ashfree dry weight (AFDW; Byers et al., 1978). DW and ASH were measured to the nearest $10^{-5}$ g with an AE240 Mettler Toledo Balance. DW, ASH and AFDW of seston and periphyton were expressed in mg. $\mathrm{L}^{-1}$ and $\mathrm{mg} \cdot \mathrm{cm}^{-2}$, respectively. The protocol used to measure DW and AFDW of seston and periphyton is described in Richard et al. (2009). In addition, three blanks of 7/16 of $200 \mathrm{ml}$ of $0.7 \mu \mathrm{m}$-filtered pond water were also analysed on each sampling date. The mean weight of the blanks was subtracted from the total periphyton DW, AFDW and $\mathrm{ASH}$. 


\section{Chlorophyll $a$ and Phaeophytin a}

In contrast to Richard et al. (2009), because of the greater periphyton development, 1/8 of periphyton was lyophilised, mixed, weighed, sub-sampled and re-weighed before Chlorophyll $a(\mathrm{Chl} a)$ and Phaeophytin $a$ (Phaeo $a$ ) analyses. Chl $a$ and Phaeo $a$ observed in water and in periphyton were determined using a Turner TD 700 fluorometer after 12 hours of acetone extraction at $4^{\circ} \mathrm{C}$ in darkness without and with acidification (Yentsch and Menzel, 1963). The ratio of Phaeo $a$ to total chlorophyll pigments was also calculated as (Phaeo $a)^{*}(\mathrm{Phaeo} a+$ $\mathrm{Chl} a)^{-1}$ and expressed in $\%$. It is called hereafter \% Phaeo $a$. Both chlorophyll pigments were expressed in $\mu \mathrm{g} . \mathrm{L}^{-1}$ in water and in $\mu \mathrm{g} . \mathrm{cm}^{-2}$ for periphyton.

\subsection{Statistical analyses}

The assumptions of normality and homoscedasticity of ANOVA were evaluated using Shapiro-Wilk (Shapiro and Wilk, 1965) and Brown-Forsythe (Brown and Forsythe, 1974) tests, respectively. When required, data were transformed to satisfy the assumptions of ANOVA (i.e. Chl $a$ ).

\section{PERIMUL: Influence of periphyton substrate and rearing density}

ANOVAs were performed to test the effects of (i) rearing density (DENS: 0, 20, 40, 60), (ii) time (TIME) and their interactions on DW, ASH, AFDW, Chl $a$, Phaeo $a$ and $\%$ Phaeo $a$ of periphyton observed on substrates. ANOVAs were also performed to test the effect of (i) substrate presence (SUBSTRATE: 0, 28), (ii) rearing density (DENS: 20, 40, 60) and their interactions (SUBSTRATE*DENS) on initial and final individual weight and standard length of fish. Cage was nested in SUBSTRATE and DENS in the latter model. In contrast, this last 
level was not added to the ANOVA of mean survival rate, and final total weight per $\mathrm{m}^{2}$, since it was only one piece of data per cage.

FEED: Feeding vs. extensive and periphyton-based systems

ANOVA was performed to test the effect of rearing system (TYPE: $\mathrm{C}=$ control, $\mathrm{S}=$ substrate, $\mathrm{F}=$ food) on initial and final individual weight and standard length of fish, survival rate and final total weight per $\mathrm{m}^{-2}$. Cage was nested in TYPE for individual weight and length.

Tukey's HSD (honestly significant difference) pairwise multiple comparison tests were used to identify the differences when a source of variation was significant $(\mathrm{P}<0.05)$.

\section{Results}

\subsection{Environmental pond conditions}

Salinity, temperature, and dissolved oxygen varied significantly according to time ( $\mathrm{p}<$ 0.0001). Salinity ranged between 26.5 and 30.1. Maximum values were recorded in June, minimum in April. Temperature ranged from 15.3 to $26.1^{\circ} \mathrm{C}$. The lowest oxygen concentration was $6.1 \mathrm{mg} . \mathrm{L}^{-1}$, the highest was $10.9 \mathrm{mg} . \mathrm{L}^{-1}$. Mean pH was 8.7 (Figure 3).

Between sampling days, the seston mean i.e. total suspended solids $( \pm$ SE) varied between $14.7 \pm 2.3$ and $90.7 \pm 6.3 \mathrm{mg} \cdot \mathrm{L}^{-1}$. The percentage of particulate inorganic matter (\% PIM) varied between $83.5 \%$ and $94.3 \%$. Chlorophyll $a$ ranged from 3.3 to $11.9 \mu \mathrm{g} . \mathrm{L}^{-1}$. The mean \% Phaeo varied from $30.8 \%$ to $56.9 \%$.

\subsection{Periphyton}

All variables describing the periphyton did not vary significantly according to the density of fish ( $\mathrm{p}>0.05)$. DW, AFDW and ASH varied significantly according to immersion time ( $\mathrm{p}$ 
$<0.0001$ ). The maximum amounts (DW and ASH) were collected on day 21, the minimum on day 35 (DW, AFDW: Table 1).

Chl $a$, Phaeo $a$ and \% Phaeo $a$ varied according to immersion time (Chl $a$ : p $<0.0001$; Phaeo $a: \mathrm{p}=0.0206 ; \%$ Phaeo $a: \mathrm{p}=0.003)$. HSD tests showed that the highest Chl $a$ mean was observed 6 days before stocking. The latter was nearly 4 times higher than the lowest one, which was recorded on day 63 (Table 1). The \% Phaeo $a$ mean was lowest before stocking with $18.2 \%$ and was, on average, $33.9 \%$ on days $21,35,49$ and 63 (Table 1).

\subsection{Fish}

\section{PERIMUL: Influence of periphyton substrate and rearing density}

Individual fish weight did not vary significantly among variation sources (SUBSTRATE, DENS, SUBSTRATE*DENS) at stocking $(\mathrm{p}=0.32)$. Fish were homogeneously distributed among cages. Mean weight ( \pm Standard Deviation SD) was $0.56 \pm 0.17 \mathrm{~g}$. Their initial mean standard length $( \pm \mathrm{SD})$ was $3.4 \pm 0.4 \mathrm{~cm}$. On day 63 , the mean individual fish weight varied between 0.47 and $4.99 \mathrm{~g}$. Their length ranged from 3.6 to $7.4 \mathrm{~cm}$. The mean standard length ( \pm SD) was $5.6 \pm 0.7 \mathrm{~cm}$. Similarly to final length, final individual fish weight varied according to rearing density $(\mathrm{p}<0.0001)$. HSD tests showed that mean individual fish weight and length were significantly higher in cages that contained the lowest densities of fish (i.e. $20>40>60$; Table 2). Survival was $94.8 \pm 1.6 \%( \pm \mathrm{SE})$ and similar for SUBSTRATE $(\mathrm{p}=$ $0.21)$, DENS $(p=0.48)$ and SUBSTRATE*DENS $(p=0.21)$. In contrast, mean final total weight differed between fish densities (DENS: $\mathrm{p}<0.0001$ ). It increased with increasing rearing density $(20<40<60$; Table 2).

FEED: Extensive systems vs. intensive system 
In contrast to stocking day (ie. day 1 , TYPE, $\mathrm{p}=0.71$ ), individual fish weight varied significantly according to the rearing system at harvesting on day 63 (TYPE, $p<0.0001$ ). It was significantly lower in fed tanks (F) than in extensive (C) and periphyton-based cages (S; Table 2). The $\%$ survival and final total weight followed the same trend (Survival: $\mathrm{p}=0.008$; Final total weight: $\mathrm{p}=0.0012$ ). The mean $\%$ survival was significantly higher in extensive and periphyton-based cages (C, S) than in fed tanks (F; Table 2). Mean total fish weight was more than double in $\mathrm{C}$ and $\mathrm{S}$ than in $\mathrm{F}$ (Table 2).

\section{Discussion}

\subsection{Periphyton}

As described in periphyton colonisation models (Hoagland et al., 1982; Steinman, 1996), AFDW and Chl $a$ levels increased until a maximum biomass was reached. After reaching the assumed carrying capacity of the substrates $\left(13.5 \pm 0.8 \mathrm{mg} . \mathrm{cm}^{-2}\right.$ at day 35$)$, the organisms close to the substrate probably became light- or nutrient-limited. Periphyton became senescent, as illustrated in this experiment by the significant increase in $\%$ Phaeo $a$ at day 21 . Periphyton started dying and sloughing (Hansson, 1992; Asaeda and Son, 2000; Azim and Asaeda, 2005), inducing a loss phase, illustrated by the decrease in DW at day 35. After this autogenic sloughing, a new accretion phase followed leading to the observed increase in AFDW from day 35 to day 63.

In contrast to previous studies (Richard et al., 2009, Richard et al., submitted), long immersion of meshed substrates (10.5 months) enabled the development of green algae and large-sized amphipods. In the same way, DW and specifically $\mathrm{Chl} a$ means were significantly higher in this experiment than in the two previous experiments during which the immersion duration of substrates were 1 and 3.5 months (Table 3 ). These observations confirm that a 
long period of substrate immersion is recommended for periphyton development. To decrease the duration of periphyton development in a temperate region, periphyton could be produced in a fertilised pond during summer when temperature and light are higher than in the rest of the year.

\subsection{Influence of artificial substrates on Liza aurata growth and production}

Mullets were seen grazing on periphyton substrates. Nevertheless, in contrast to the observations of Keshavanath et al. (2001), fish density did not affect the periphyton biomass (DW and AFDW) on substrates. Suspended meshed substrates were flexible. When the mullets tried to eat on the substrate, they rather pushed it away than ate on periphyton. This could also explain why the periphyton did not rejuvenate since $\%$ Phaeo $a$ increased with time. Had it been effective grazing, the \% Phaeo $a$ would not rise, as Azim et al. (2002b) observed in a periphyton-based system of Indian major carps. In contrast to the observations of Milstein et al. (2009) for tilapia, substrate addition did not affect final individual weight and final biomass of mullets at harvest. Assuming that the periphyton AFDW of substrate was equivalent on substrate and on cage walls, from the biomass increase in periphyton between days 35 and 63, a maximum periphyton production of $1.44 \mathrm{~g} \mathrm{AFDW.cage} \mathrm{e}^{-1} \cdot \mathrm{d}^{-1}$ was estimated for control cages. The maximal fish yield reached $88.7 \mathrm{~g}$ per cage after 63 rearing days, i.e. a maximal fish production of $1.41 \mathrm{~g}$ fresh weight.cage ${ }^{-1} \cdot \mathrm{d}^{-1}$. Based on an average FCR value of 1.2 on a periphyton AFDW basis for tilapia and $70 \%$ use of total biomass (Azim et al., 2001b), this production would be possible if the AFDW production was $2.41 \mathrm{~g}$ AFDW.cage ${ }^{-}$ ${ }^{1} \cdot \mathrm{d}^{-1}$. Mullets probably ate on walls but also on mud accumulated on the bottom of control cages. In substrate cages, maximum periphyton production was estimated at $2.45 \mathrm{~g}$ AFDW.cage ${ }^{-1} \cdot d^{-1}$; i.e. periphyton alone could contribute to fish production. In subsequent studies, meshed substrates could be attached on rigid structures to render them inflexible and 
to improve the efficiency of mullet grazing, as was done with poles in carp (Azim et al., 2001a) and tilapia periphyton-based ponds (Keshavanath et al., 2004). Moreover, as used in freshwater (Azim et al., 2001b), fertilisation could be envisaged to maximise periphyton production. In fertilised ponds, Azim et al. (2001b) observed a maximum periphyton AFDW production of $2.56 \mathrm{~g}$ vs. $1 \mathrm{~g}$ AFDW. $\mathrm{m}^{-2} \cdot \mathrm{day}^{-1}$ in this experiment where no fertilization occurred. Furthermore, as Liza aurata only became benthic-herbivorous at 45-50 mm (Bruslé, 1981), rearing larger juveniles and adults might be more successful in periphyton-based systems.

\subsection{Influence of stocking density on Liza aurata growth and production}

The mean survival rate of the mullets $(\approx 95 \%)$ was better than in other studies where survival of $L$. aurata juveniles ( $1 \mathrm{~g}$ ) varied from 40 to $60 \%$ after 150 to 243 rearing days in extensive and semi-intensive systems (Chervinsky et al., 1975; Sadek et al., 1986). Survival rate was independent of stocking density. As with tilapia (Azim et al., 2003) and seabream (Richard et al., submitted), mullets grew faster at low rearing density in an extensive system, probably due to less competition for food and/or space. Food availability for mullets was not limiting in substrate-free cages since the final total mullet weight increased with stocking density. Eating on periphyton substrates was probably not a necessity for mullets during this experiment. Stocking density could be increased to render food availability limiting in substrate-free cages and to force mullets to eat on inflexible periphyton substrates in substrate cages.

\subsection{Influence of extensive systems vs. intensive system}

In contrast to seabream (Richard et al. submitted), the survival, growth and production of mullets were better in extensive ( $\mathrm{C}$ cages) and periphyton-based systems ( $\mathrm{S}$ cages) than in fed 
systems. As in this study, Pruginin et al. (1975) observed that, although mullets fed on pellets, they did not seem to grow faster. Natural food and marine ponds were more appropriate for rearing mullet than the Classic C2 dry feed and fibreglass tanks. Tanks received $315 \mathrm{~g}$ dry feed, while the fish weight increase was only $14.7 \mathrm{~g}$ after 63 days. If all feed had been eaten, the FCR would have been 21.4. This is unacceptably high. Indeed, Mugil cephalus achieved an FCR of 1.6 when fed rice and peanut oil cake (Gautier and Hussenot, 2005). In this investigation, a large fraction of the dry feed was probably not eaten. The walls of tanks were observed to be dirty after one week. Although fish did not seem to be stressed in rearing tanks, they could have been and thus eaten less than in extensive ponds where stress factors were lower. Moreover, in contrast to aquaculture juveniles, these wild mullet juveniles were probably not accustomed to the dry feed. Furthermore, the latter was probably not a welladapted and balanced mullet diet, but no better specific feed was available in France and Italy. This research suggests that extensive rearing of mullets in marine ponds could be more efficient than rudimentary intensive rearing in artificial rearing devices. Nevertheless, the production of mullets in artificial rearing devices could be improved by better management (filtration and nutrition) which could reduce fish stress during cleaning and increase fish appetite.

\subsection{Comparison with fish growth and production in other mullet rearing systems}

The maximal daily individual growth was $0.04 \mathrm{~g} \cdot \mathrm{d}^{-1}$. This is significantly lower than that observed in other extensive rearing systems of Liza aurata juveniles where growth rate was $0.22 \mathrm{~g} . \mathrm{d}^{-1}$ with (i) an initial weight of $1 \mathrm{~g}$, (ii) a final weight of $80 \mathrm{~g}$ (iii) 355 days of rearing and (iv) a water temperature ranging from 17 to $32^{\circ} \mathrm{C}$ (Chervinski, 1975). This growth rate was lower than that observed in semi-intensive ponds where Liza aurata juveniles were fed 
ad libitum with pellets (0.6 to $1 \mathrm{~g} . \mathrm{d}^{-1}$; Chervinski, 1975). Nevertheless, in this rearing system, the initial biomass of mullet juveniles was significantly lower $\left(1 \mathrm{~g}\right.$ x 0.3 to 0.7 ind. $\mathrm{m}^{-2}=0.3$ to $\left.0.7 \mathrm{~g} \cdot \mathrm{m}^{-2}\right)$ than that used in this investigation $\left(0.56 \times 20\right.$ ind. $\left.\mathrm{m}^{-2}=11.2 \mathrm{~g} \cdot \mathrm{m}^{-2}\right)$. The food availability per individual must have been greater in these other mullet rearing systems, which explains these higher individual growth rates. In future studies, to increase the individual growth rate of mullets, initial stocking density should be decreased. However, in this study, the production of mullets (net yield per rearing day) varied from 0.79 to $1.41 \mathrm{~g} \cdot \mathrm{m}^{-2} \cdot \mathrm{d}^{-1}$ depending on rearing density. This is significantly higher than the Liza aurata production of semi-intensive systems $\left(0.15\right.$ to $0.22 \mathrm{~g} \cdot \mathrm{m}^{-2} \cdot \mathrm{d}^{-1}$; Chervinski, 1975). In the same way, Sadek et al. (1986) obtained a low net yield of $0.14 \mathrm{~g} \cdot \mathrm{m}^{-2} \cdot \mathrm{d}^{-1}$ in a semi-intensive polyculture of mullets (L. ramada, L. scheli and Mugil cephalus). Azim et al. (2002a) synthesised the results of fish yield of several periphyton-based systems of Rohu, Catla, Kalbaush and Tilapia. According to these data, the fish yield in periphyton-based systems varied from 0.6 to $2.2 \mathrm{~g} \cdot \mathrm{m}^{-2} \cdot \mathrm{d}^{-1}$. The yield recorded in this investigation corresponds more to the yield of periphyton-based systems than that of extensive or semi-intensive cultures. The presence of periphyton on inflexible wall cages could have increased the food availability and the natural productivity of the rearing system.

Finally, the final mullet biomass at harvest $\left(122 \mathrm{~g} \cdot \mathrm{m}^{-2}\right)$ was nearly 10 times higher than for seabream (13 g.m ${ }^{-2}$ : Richard et al. submitted). This investigation confirmed that, in extensive ponds, it is more advantageous to rear herbivorous and omnivorous than carnivorous fish.

\subsection{Perspectives for sustainable mullet rearing}

Whereas in France consumers prefer L. aurata over thick-lipped mullet (Chelon labrosus), the latter is a candidate species for rearing in periphyton-based systems. Chelon labrosus is known to grow faster than Liza aurata and L. ramada (Gautier and Hussenot, 
2005). When one-year old, the weight of Chelon labrosus ranged from 9 to $30 \mathrm{~g}$ whereas Liza aurata weight varied from 6 to $8 \mathrm{~g}$ in their natural habitat in France (Gautier and Hussenot, 2005). Chelon labrosus prefer rocky habitats (Lam Hoai Thong, 1969). However, they adapt to ponds with a mud bottom (Gautier and Hussenot, 2005). Hickling (1970) observed that thick-lipped mullet mainly ate harpacticoid copepods and micro-algae that were observed on periphyton substrates (Richard et al. submitted). It is recommended that C. labrosus be tested in a periphyton-based pond, as the fish production is expected to be better than with L. aurata. Nevertheless, substrates must be rigid to enable the fish to graze on them as they do on a rock.

As part of the EU policy of environmental protection and restoration of coastal areas, one of the best solutions for sustainable aquaculture in Southern Europe would be to exploit the effluents of marine intensive farms in periphyton and mullet production. L. aurata and $C$. labrosus production could be marketed as fillets from regional and sustainable aquaculture. Moreover, long-term rearing of Mugil cephalus could be interesting through the sale of dried roe, called Boutargue or Poutargue, which is a gourmet food of very high price (Liao, 1975), much appreciated on the Mediterranean coast (Beddih et al., 2005).

\section{Acknowledgments}

This study has been carried out with the financial support from the Commission of the European Communities, specific RTD programme "Specific Support to Policies", SSP-200544483 "SEACASE - Sustainable extensive and semi-intensive coastal aquaculture in Southern Europe", and does not necessarily reflect the European Commission views and in no way anticipates the Commission's future policy in this area. This study was co-funded by the IFREMER institute. This article was written thanks to the administrative help of S. Lamare, P. Bustamante, L. Picard and H. Thomas-Guyon (CNRS, UMR 6250, University of La Rochelle). Thanks to Venetian farmers for selling us juvenile mullets. The authors thank M. 
Prineau and N. Lachaussée for their advice and help during structure and substrate construction. Thanks go to our student trainees, A. Anginot and J.T. Maurice, and to our colleagues, F. Paticat, D. Leguay, C. Arnaud, and F. Mornet, for their help in the field in 2008. The authors thank A. Bodoy, M.L. Begout, M. Breret, X. Cousin, L. Joassard, B. Lebreton and P. Richard for the loan of materials. Finally, thanks are also due to C. Robins for the revision of the English of this manuscript.

\section{References}

Asaeda, T., Son, H.D., 2000. Spatial structure and populations of a periphyton community: a model and verification. Ecol. Model. 133, 195-207.

Azim, M.E., Asaeda, T., 2005. Periphyton structure, diversity and colonization. In: Azim, M.E., Beveridge, M.C.M., van Dam, A.A., Verdegem, M.C.J. (Eds.), Periphyton: Ecology, exploitation and management. CABI Publishing, pp. 15-34.

Azim, M.E., Verdegem, M.C.J., van Dam, A.A., Beveridge, M.C.M., 2005. Periphyton: Ecology, exploitation and management. CABI Publishing, 319 pp.

Azim, M.E., Verdegem, M.C.J., Singh, M., van Dam, A.A., Beveridge, M.C.M., 2003. The effects of periphyton substrate and fish stocking density on water quality, phytoplankton, periphyton and fish growth. Aquac. Res. 34, 685-695.

Azim, M.E., Wahab, M.A., van Dam, A.A., Beveridge, M.C.M., Verdegem, M.C.J., 2001a. The potential of periphyton-based culture of two Indian major carps, rohu Labeo rohita (Hamilton) and gonia Labeo gonius (Linnaeus). Aquac. Res. 32, 209-216.

Azim, M.E., Verdegem, M.C.J., Khatoon, H., Wahab, M.A., van Dam, A.A., Beveridge, M.C.M., 2002a. A comparison of fertilization, feeding and three periphyton substrates for 
increasing fish production in freshwater pond aquaculture in Bangladesh. Aquaculture $212,227-243$.

Azim, M.E., Verdegem, M.C.J., Rahman, M.M., Wahab, M.A., van Dam, A.A., Beveridge, M.C.M., 2002b. Evaluation of polyculture of Indian major carps in periphyton-based ponds. Aquaculture 213, 131-149

Azim, M.E., Wahab, M.A., Biswas, P.K., Asaeda, T., Fujino, T., Verdegem, M.C.J., 2004. The effect of periphyton substrate density on production in freshwater polyculture ponds. Aquaculture 232, 441-453.

Azim, M.E., Wahab, M.A., Van Dam, A.A., Beveridge, M.C.M., Milstein, A., Verdegem, M.C.J. 2001b. Optimization of fertilization rate for maximizing periphyton production on artificial substrates and the implications for periphyton-based aquaculture. Aquac. Res. $32,749-760$.

Beddih, M.L.O.A., El Cafsi, M., Marzouk, B., Zarrouk, K., Rombhane, M. S. 2005. Compositions chimiques et énergétiques des boutargues du mulet Mugil cephalus et de la courbine Argyrosomus regius en Mauritanie. Bull. Inst. Natn. Scien. Tech. Mer de Salammbô 32, 31-37.

Brown, M.B., Forsythe, A.B., 1974. Robust tests for the equality of variances. J. Am. Stat. Ass. 69, 364-367.

Bruslé, J., 1981. Food and feeding in grey mullets. In: Oren O.H. (ed.), Aquaculture of grey mullets, Cambridge University Press, Cambridge, 185-217.

Byers, S.C., Mills, E.L., Stewart, P.L., 1978. A comparison of methods of determining organic carbon in marine sediments, with suggestions for a standard method. Hydrobiologia 58, 43-47.

Chervinski, J., 1975. Experimental raising of golden grey mullet (Liza aurata (Risso)) in saltwater ponds. Aquaculture 5, 91-98. 
Gautier, D., Hussenot, J., 2005. les mulets des mers d'Europe: Synthèse des connaissances sur les bases biologiques et les techniques d'aquaculture. IFREMER publishing. pp. 118.

Hansson, L.A., 1992. Factors regulating periphytic algal biomass. Limnol. Oceanogr. 37, 322328.

Hickling, C.F., 1970. A contribution to the natural history of the English grey mullets. J. Mar. Biol. Ass. UK, 50, 609-633.

Hoagland, K.D., Roemer, S.C., Rosowski, J.R., 1982. Colonization and community structure of two periphyton assemblages with emphasis on the diatoms (Bacillariophyceae). Am. J. Bot. 69, 188-213.

Huchette, S.M.H., Beveridge, M.C.M., 2005. Periphyton-based cage aquaculture, Periphyton: Ecology, exploitation and management. CABI Publishing, pp. 237-245.

Keshavanath, P., Gangadhar, B., Ramesh, T.J., van Dam, A.A., Beveridge, M.C.M., Verdegem, M.C.J., 2004. Effects of bamboo substrate and supplemental feeding on growth and production of hybrid red tilapia fingerlings (Oreochromis mossambicus $\mathrm{x}$ Oreochromis niloticus). Aquaculture 235, 303-314.

Keshavanath, P., Gangadhar, B., Ramesh, T.J., van Rooij, J.M., Beveridge, M.C.M., Baird, D.J., Verdegem, M.C.J., van Dam, A.A., 2001. Use of artificial substrates to enhance production of freshwater herbivorous fish in pond culture. Aquac. Res. 32, 189-197.

Lam Hoai Thong, 1969.Contribution à l'étude de la biologie des mugilidés (poissons téléostéens) des côtes du Massif armoricain; Tav. Fac. sci. Rennes, Série Océnogr. biol., $2,55-182$.

Liao, J.C., 1975. Experiment on induced breeding of the grey mullet in Taiwan from 1963 to 1973. Aquaculture 6, 31-58.

Milstein, A., Peretz, Y., Harpaz, S., 2009. Culture of organic tilapia to market size in periphyton-based ponds with reduced feed inputs. Aquac. Res. 40, 55-59. 
Motoda, 1969. Devices of simple plankton apparatus, Faculty of Fisheries. Hokkaido University, pp. 73-94.

Pruginin, Y., Shilo, S., Mires, D., 1975. Grey mullet: a component in polyculture in Israel. Aquaculture 5, 291-298.

Ramesh, M.R., Shankar, K.M., Mohan, C.V., Varghese, T.J., 1999. Comparison of three plant substrates for enhancing carp growth through bacterial biofilm. Aquac. Eng. 19, 119-131.

Richard, M., Trottier, C., Verdegem, M.C.J, Hussenot, J., 2009. Submersion time, depth, substrate type and sampling method as variation sources of marine periphyton. Aquaculture 295, 209-217

Richard, M., Trottier, C., Olivier, S., Pavie, L., Verdegem, M.C.J, Hussenot, J., submitted. Extensive Sparus aurata nurseries: effect of periphyton substrates and rearing density. Aquaculture

Sadek, S., Ittawa, I., Marcello, R., 1986. Culture of mullet species in ponds receiving iron crush effluents at Elbaharia oasis, Egypt. Aquaculture 59, 23-29.

Shapiro, S.S., Wilk, M.B., 1965. An analysis of variance test for normality (complete samples). Biometrika 52, 591-611.

Steinman, A.D., 1996. Effect of grazers on freshwater benthic algae, Algal ecology: freshwater benthic ecosystems. Academic Press, San Diego, California, pp. 341-373.

Umesh, N.R., Shankar, K.M., Mohan, C.V., 1999. Enhancing growth of common carp, rohu and Mozambique tilapia through plant substrate: the role of bacterial biofilm. Aquac. Int. 7, 251-260.

van Dam, A.A., Beveridge, M.C.M., Azim, M.E., Verdegem, M.C.J., 2002. The potential of fish production based on periphyton. Rev. Fish Biol. Fish. 12, 1-31.

Yentsch, C.S., Menzel, D.W., 1963. A method for the determination of phytoplankton chlorophyll and phaeophytin by fluorescence. Deep Sea Res. 10, 221-231. 


\section{Figures}

Figure 1: Experimental design composed of two factors (i) periphyton (SUBSTRATE; 0: no substrate, 28: meshed substrates) and (ii) fish rearing density (DENS; 0, 20, 40, 60 mullets. cage $^{-1}$ ), with 3 replicates per treatment.

Figure 2: Experimental design comparing rearing type (TYPE; C: substrate-free cages, S: meshed-substrate cages, F: fed tanks), with 3 replicates per TYPE.

Figure 3: Daily data of salinity, temperature, oxygen and $\mathrm{pH}$ measured at 3 different places in the experimental pond, using a HANNA probe, during the whole experiment (23 April to 23 June 2008). 


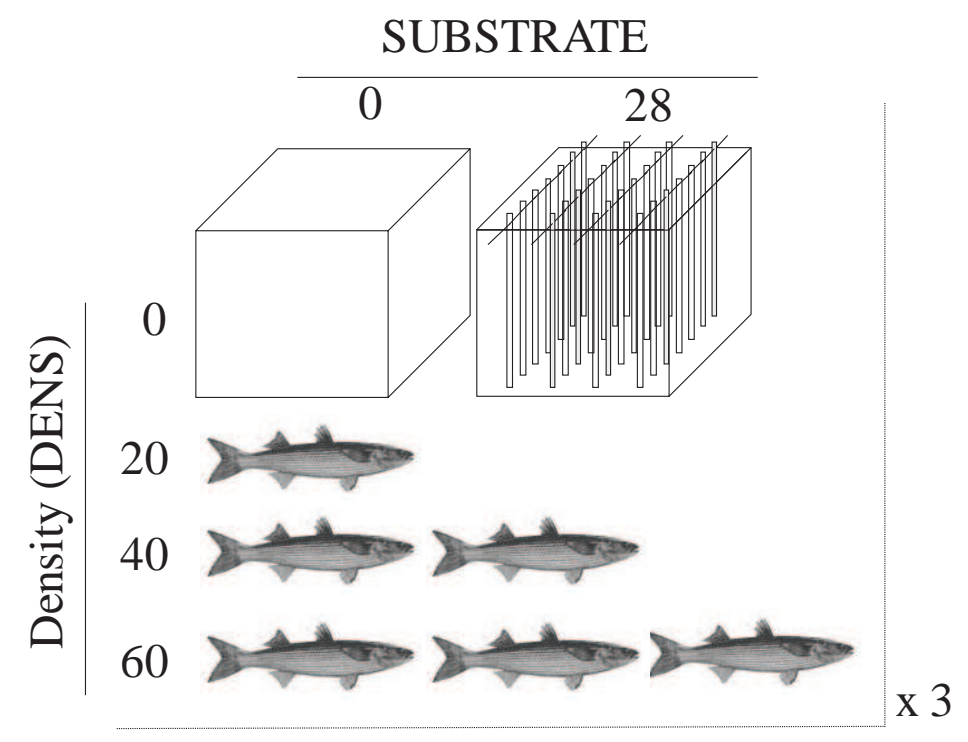

Figure 1. Richard et al. 


\section{TYPE}

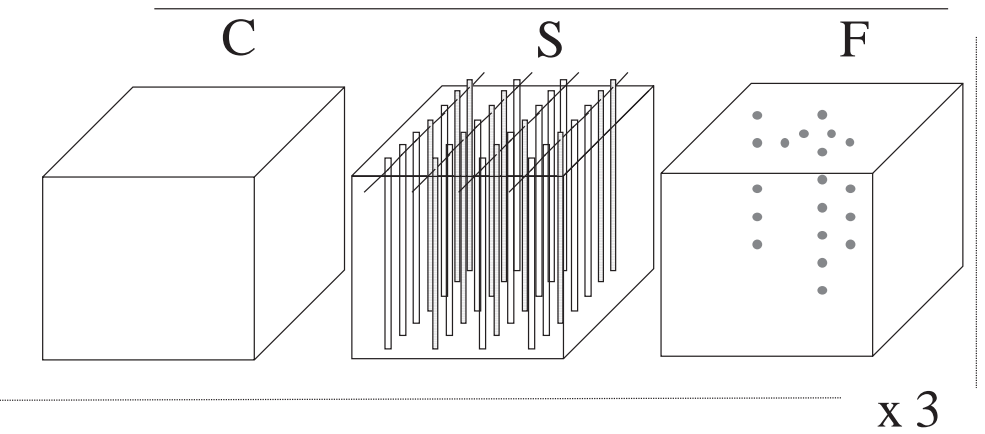

Figure 2. Richard et al. 


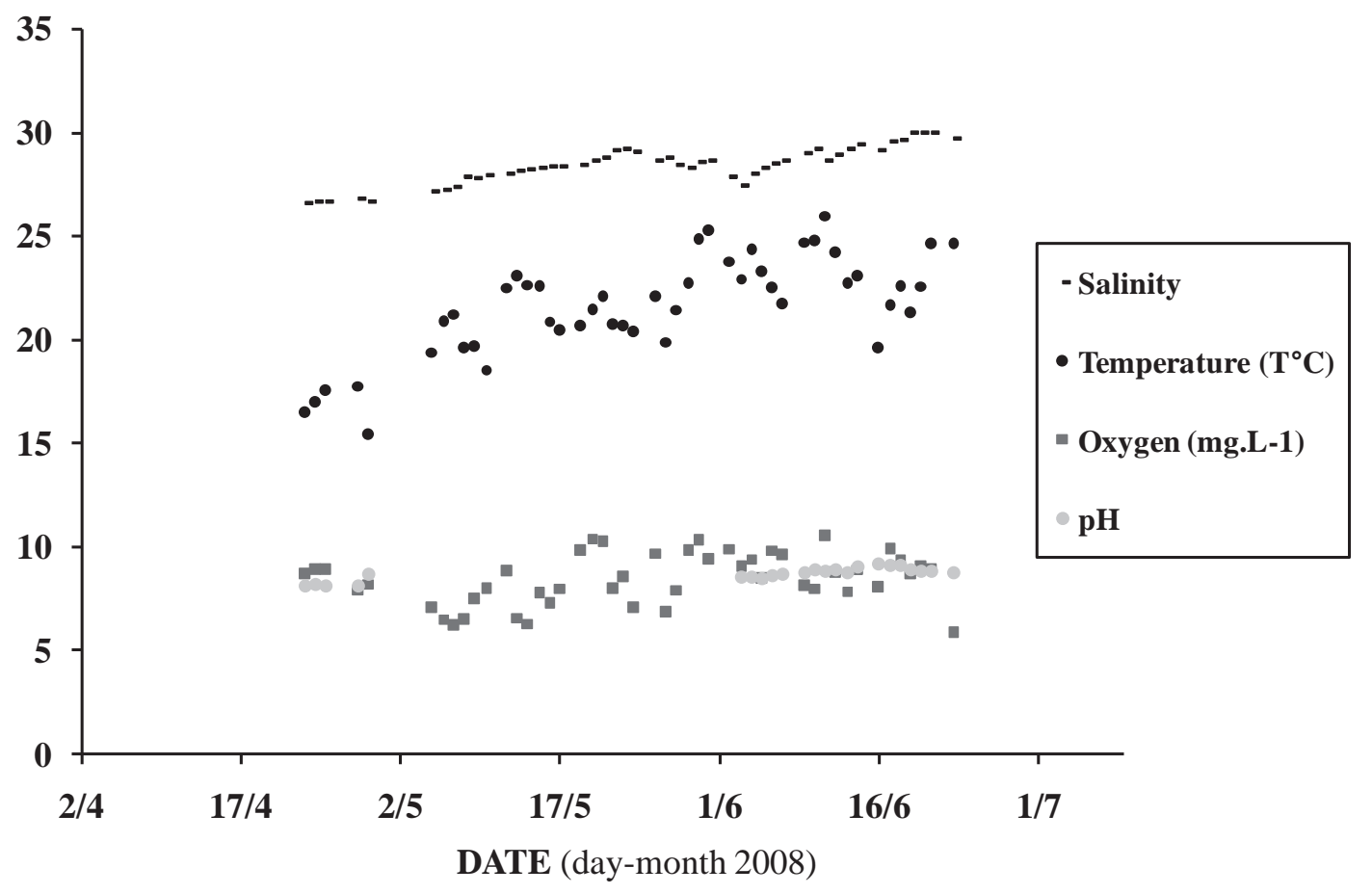

Figure 3. Richard et al. 
Periphyton-based system of mullets

\section{Tables}

Table 1

Mean $( \pm$ SE) of periphyton dry weight (DW), ash weight (ASH), ash-free dry weight (AFDW), Chlorophyll $a(\mathrm{Chl} a$ ), Phaeophytin $a$ (Phaeo $a$ ) and percent of Phaeophytin $a$ vs. total pigment (Phaeo $a$ ) observed on substrates according to different levels of fish density (DENS: 0, 40, 60 fish per cage) and TIME (-6, 21, 35, 49, 63 days). Different letters indicate statistical difference among levels within a variation source.

\begin{tabular}{|c|c|c|c|c|c|c|c|}
\hline $\begin{array}{c}\text { Variation } \\
\text { source }\end{array}$ & Level & $\begin{array}{c}\text { DW } \\
\left(\mathrm{mg} \cdot \mathrm{cm}^{-2}\right)\end{array}$ & $\begin{array}{c}\mathrm{ASH} \\
(\mathrm{mg} . \mathrm{cm}-2)\end{array}$ & $\begin{array}{c}\text { AFDW } \\
\text { (mg.cm-2) }\end{array}$ & $\begin{array}{c}\text { Chl } a \\
(\mu \mathrm{g} . \mathrm{cm}-2)\end{array}$ & $\begin{array}{c}\text { Phaeo } a \\
(\mu \mathrm{g} . \mathrm{cm}-2)\end{array}$ & $\begin{array}{c}\text { Phaeo } a \\
(\%)\end{array}$ \\
\hline \multirow[t]{4}{*}{ DENS } & 0 & $9.4 \pm 0.8$ & $7.8 \pm 0.7$ & $1.5 \pm 0.2$ & $7.2 \pm 1.8$ & $2.8 \pm 0.4$ & $31.6 \pm 2.9$ \\
\hline & 20 & $10.0 \pm 0.7$ & $8.4 \pm 0.6$ & $1.6 \pm 0.1$ & $7.6 \pm 1.7$ & $2.2 \pm 0.3$ & $27.0 \pm 3.5$ \\
\hline & 40 & $10.2 \pm 1.0$ & $8.5 \pm 0.9$ & $1.7 \pm 0.2$ & $5.0 \pm 0.8$ & $1.9 \pm 0.2$ & $28.5 \pm 2.5$ \\
\hline & 60 & $11.1 \pm 1.0$ & $9.2 \pm 0.8$ & $1.9 \pm 0.2$ & $6.9 \pm 1.8$ & $2.9 \pm 0.4$ & $33.1 \pm 3.8$ \\
\hline \multirow[t]{5}{*}{ TIME } & -6 & $10.9 \pm 0.4 \mathbf{b}, \mathbf{c}$ & $8.7 \pm 0.4 \mathbf{a}$ & $2.3 \pm 0.1 \mathrm{c}$ & $13.9 \pm 2.0 \mathbf{c}$ & $2.8 \pm 0.3 \mathbf{a , b}$ & $18.2 \pm 1.9 \mathbf{a}$ \\
\hline & 21 & $13.5 \pm 0.8 \mathbf{c}$ & $11.6 \pm 0.7 \mathbf{b}$ & $1.9 \pm 0.2 \mathbf{b}, \mathbf{c}$ & $5.8 \pm 0.5 \mathbf{a}, \mathbf{b}$ & $3.2 \pm 0.5 \quad$ b & $34.7 \pm 4.0 \mathbf{b}$ \\
\hline & 35 & $7.1 \pm 0.8 \mathbf{a}$ & $6.3 \pm 0.7 \mathbf{a}$ & $0.8 \pm 0.1 \mathbf{a}$ & $n d$ & $n d$ & $n d$ \\
\hline & 49 & $9.3 \pm 0.7 \mathbf{a , b}$ & $8.0 \pm 0.6 \mathbf{a}$ & $1.3 \pm 0.2 \mathbf{a}, \mathbf{b}$ & $4.3 \pm 0.3 \mathbf{a}, \mathbf{b}$ & $2 \pm 0.3$ a,b & $32 \pm 2.3 \mathbf{b}$ \\
\hline & 63 & $9.9 \pm 1.1 \mathbf{a , b}$ & $7.7 \pm 0.9 \mathbf{a}$ & $2.2 \pm 0.2 \mathrm{c}$ & $3.4 \pm 0.3 \mathbf{a}$ & $1.8 \pm 0.2 \mathbf{a}$ & $34.7 \pm 2.1 \mathbf{b}$ \\
\hline
\end{tabular}


Periphyton-based system of mullets

\section{Table 2}

Mean $( \pm$ SE) of individual weight $(\mathrm{g})$, final standard length $(\mathrm{cm})$, survival rate $(\%)$ and final total weight $\left(\right.$ g.cage $\left.^{-1}\right)$ according to different levels of (i) SUBSTRATE (0, 28 substrates per cage) and DENS (20, 40, 60 fish per cage) for the first experiment (PERIMUL) and (ii) TYPE (C: control, S: substrate, F: food) for the second experiment (FEED). Different letters indicate statistical difference among levels within a variation source.

\begin{tabular}{|c|c|c|c|c|c|c|c|}
\hline $\begin{array}{l}\text { Experiment } \\
\text { name }\end{array}$ & $\begin{array}{l}\text { Variation } \\
\text { source }\end{array}$ & Level & $\begin{array}{l}\text { Individual } \\
\text { weight (g) }\end{array}$ & $\begin{array}{c}\text { Final } \\
\text { standard } \\
\text { length }(\mathrm{cm})\end{array}$ & $\begin{array}{c}\text { Survival rate } \\
(\%)\end{array}$ & $\begin{array}{l}\text { Final total } \\
\text { weight } \\
\left(\text { g.cage }^{-1}\right)\end{array}$ & \\
\hline \multirow[t]{5}{*}{ PERIMUL } & SUBSTRATE & 0 & $2.36 \pm 0.05$ & $5.59 \pm 0.05$ & $96.19 \pm 1.13$ & $97.76 \pm 11.19$ & \\
\hline & & 28 & $2.48 \pm 0.05$ & $5.71 \pm 0.04$ & $93.65 \pm 1.60$ & $88.49 \pm 9.16$ & \\
\hline & DENS & 20 & $3.28 \pm 0.09 \mathrm{c}$ & $6.31 \pm 0.06 \mathbf{c}$ & $93.00 \pm 2.55$ & $61.28 \pm 2.24$ & $\mathbf{a}$ \\
\hline & & 40 & $2.44 \pm 0.05 \mathrm{~b}$ & $5.65 \pm 0.05 \mathbf{b}$ & $96.50 \pm 1.27$ & $94.88 \pm 2.49$ & b \\
\hline & & 60 & $2.11 \pm 0.05 \mathrm{a}$ & $5.43 \pm 0.04 \mathbf{a}$ & $95.00 \pm 1.18$ & $122.29 \pm 5.97$ & c \\
\hline \multirow[t]{3}{*}{ FEED } & TYPE & $\mathrm{C}$ & $3.19 \pm 0.13 \mathrm{~b}$ & $6.32 \pm 0.09 \mathbf{b}$ & $97.50 \pm 2.50 \mathbf{b}$ & $62.71 \pm 2.81$ & b \\
\hline & & S & $3.34 \pm 0.12 b$ & $6.31 \pm 0.08 \mathbf{b}$ & $90.00 \pm 2.89 \mathbf{b}$ & $60.32 \pm 3.60$ & b \\
\hline & & $\mathrm{F}$ & $2.00 \pm 0.08 \mathrm{a}$ & $5.32 \pm 0.07 \mathbf{a}$ & $65.00 \pm 5.77 \mathbf{a}$ & $26.18 \pm 3.55$ & 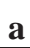 \\
\hline
\end{tabular}


Periphyton-based system of mullets

\section{Table 3}

Comparison of DW and Chl $a$ means observed during the SEACASE studies on periphytonbased systems.

\begin{tabular}{llrllll}
\hline & Subject & $\begin{array}{c}\text { Months of } \\
\text { immersion }\end{array}$ & $\begin{array}{l}\text { DW mean } \\
\left(\mathrm{mg} . \mathrm{cm}^{-2}\right)\end{array}$ & $\begin{array}{c}\text { Chl } a \text { mean } \\
\left(\mu \mathrm{g} . \mathrm{cm}^{-2}\right)\end{array}$ \\
\hline This study & Mullet & 10.5 & $10.1 \pm 3.4$ & $\mathbf{b}$ & $6.8 \pm 5.2$ & $\mathbf{b}$ \\
Richard et al. submitted & Seabream & 3.5 & $8.9 \pm 4.4$ & $\mathbf{a , b}$ & $2.8 \pm 1.9$ & $\mathbf{a}$ \\
Richard et al. 2009 & Periphyton & 1 & $6.4 \pm 3.3$ & $\mathbf{a}$ & $0.7 \pm 0.2$ & $\mathbf{a}$ \\
\hline
\end{tabular}

